\title{
MRF ダンパの応用事例
}

MR Damper Applications Overview

木 本 彰**ロード・ファー・イースト・インコーポレイテッド Akira Kimoto* *LORD FAR EAST INC.

\section{MR 流体の特徵}

MR 流体は, 印加磁場に比例して見掛けの粘度が変化す る機能性流体であり，鉄粉，分散媒，添加剂から構成され， 含まれる鉄粉量が多くなればなるほど，同じ磁場強度に対 する降伏応力は高くなる性状を持つ.

自動車用サスペンションに実用化される際に, 耐環境性や 耐久性などの MR 流体の実用性能が厳しく評価された [1]. 例えば寒冷地（Michigan）と酷暑地（Texas）で実車走行 した後加速試験では 19 万キロ程度相当まで印加時の減衰 力変化がほとんどないことが確認されている（図 1).

また, 沈降性の評価として, 一年間静置後のダンパを, 無 印加で動作させたときの減衰力を調べたところ, 最初のス トロークのみ高い值を示すが，以降は一度ストロークすれ ば，通常值に戻るという結果であった（図 2 ）。

これらの評価の結果, 採用に至りすでに 10 年弱が経過 しているが，その間順調に採用車種を増やし続けているこ とから，MR 流体自体の性能は十分実用化の域に到達して いることが実績の面からも裏付けられていると考えられる.

\section{2.これまでの主な実用化事例}

MR 流体を応用する場合, 主に図 3 に示す二つのモード が用いられている。 バルブモードは直動ダンパやマウント， シアーモードは回転形のブレーキやクラッチなどのデバイ スに応用されているが，これまで量産化されているものは ほとんどがバルブモードのデバイスである．

バルブモードで応用する場合の機器構造例を図 4 に示す. ピストン内に埋め込まれたコイルに電流を流し，ピストン 内部に設けた流路, もしくはピストン外周とシリンダ内壁 間に磁場を印加することで流路に閉塞効果が発現し，それ によりピストンの動きが妨げられ，抵抗力となる.

以下これまでの実用化された事例を示す。

原稿受付 2013 年 2 月 27 日

キーワード : Magnetorheological Fluid, MR, Controllable, Damper, Suspension

* $\bar{\top} 160-0023$ 新宿区西新宿 8-4-2

*Shinjyuku-ku, Tokyo

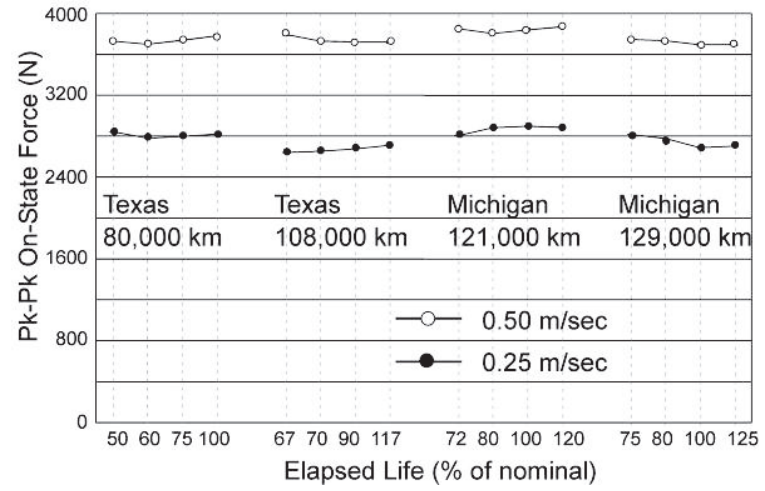

図 1 走行距離に対する減衰力変化

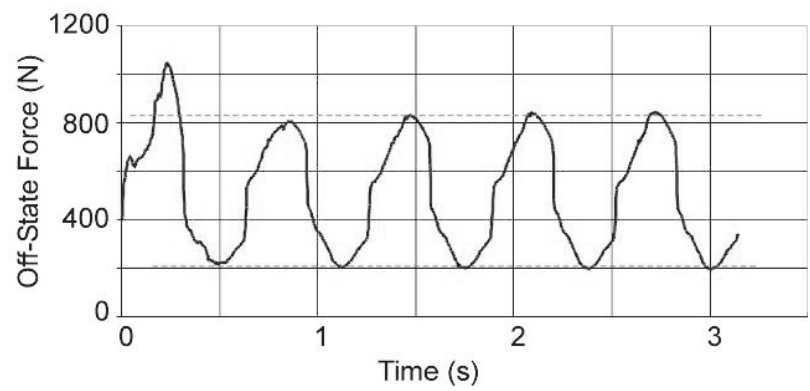

図 2 一年間静置後の初ストローク時の減衰力変化

バルブモード(圧力流れ型)

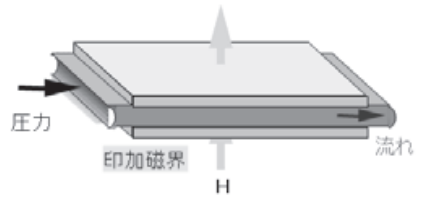

シアーモード(せん断型)

図 3 MR 流体の代表的応用モード

\section{1 自動車用サスペンション}

自動車部品メーカが MR 流体を用いて 2002 年より自動 車用 MR サスペンションシステムを実用化し, 現在も性能 を向上させながら搭載車種を増やし続けている．第三世代 では基本構造から見直された結果, 減衰力の制御幅が広が るとともに応答性も更に向上し, 立ち上がりで $14[\mathrm{~ms}]$, 立 ち下がりでも $13[\mathrm{~ms}]$ で減衰力を $10 \%$ 90\%まで変化させ ることができるようになっている $[2]$. 


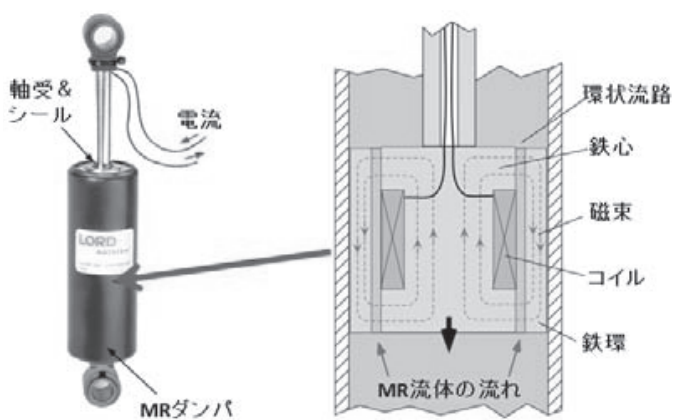

図 4 バルブモードを応用したダンパ構造例

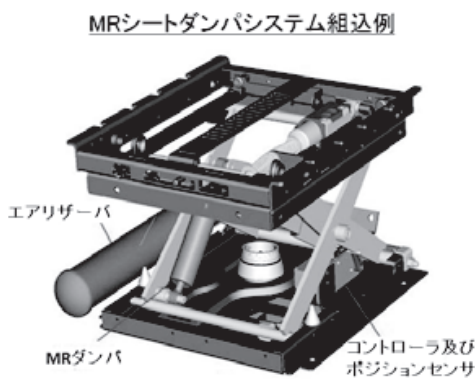

システム構成

図 5 シートサスペンションシステム
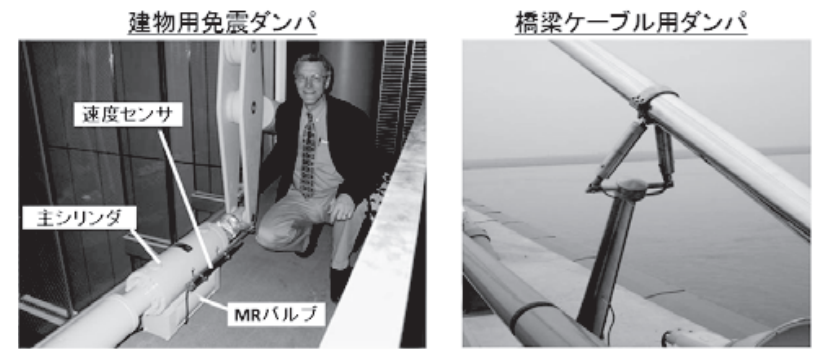

図 6 インフラ用 MR ダンパ

\section{2 シートサスペンション}

大型車両の運転席サスペンション用に MR ダンパ，セン サおよびコントローラがセットになったシステムが，1998 年から現在累計で 3 万台を超える車両で使われている（図 5). MR ダンパを用いることでシート上での最大加速度を 最大 $46 \%$ 押さえられることも報告されている [3].

\section{3 土木建築用途}

2001 年に日本の科学未来館が, MR の大型 30 [t] ダンパ を 2 本使用した建物免震システムを採用した。また 2002 年には, 中国の斜長橋でケーブルの振動制御に小型 MR ダ ンパが採用されている（図6)。

\section{4 医療用途}

2001 年に欧州の医療機器メーカで, 関節部分に MR ダ ンパを用いた義足が実用化されている（図 7)。日本でも MR デバイスを用いたリハビリ装置などが幅広く研究され ている.

2.5 自動車用エンジンマウント

MR 流体を用いた自動車用セミアクティブエンジンマウ
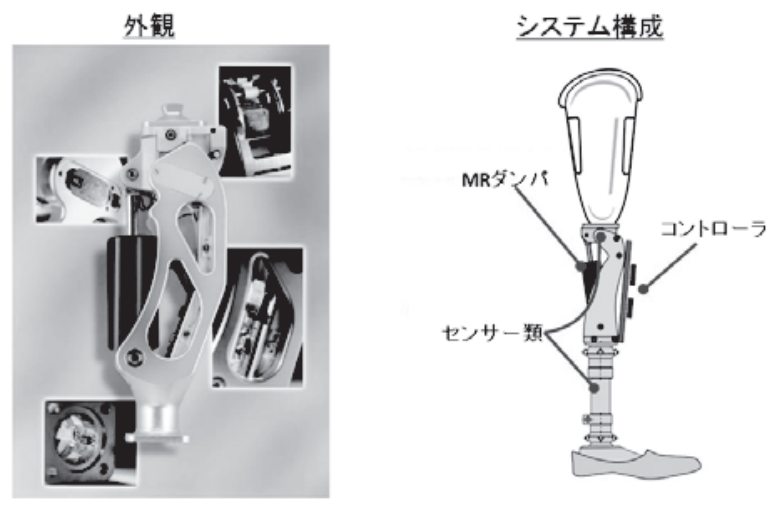

図 7 MR ダンパを用いた義足
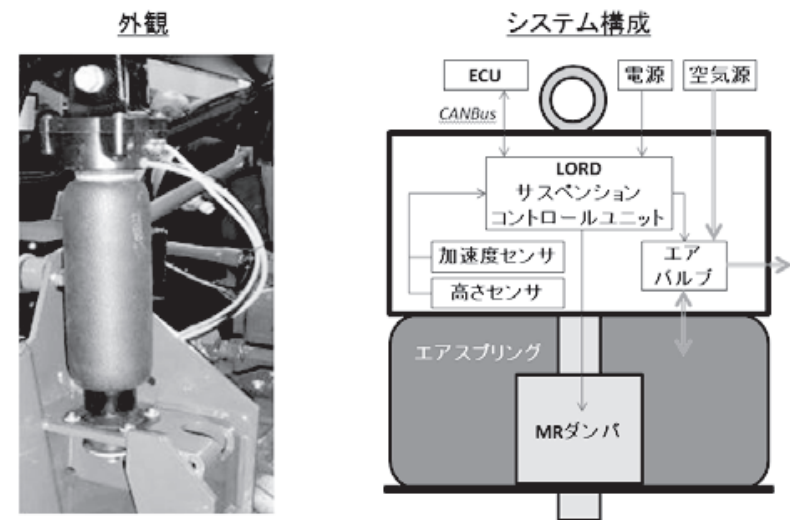

図 8 キャブサスペンションシステム

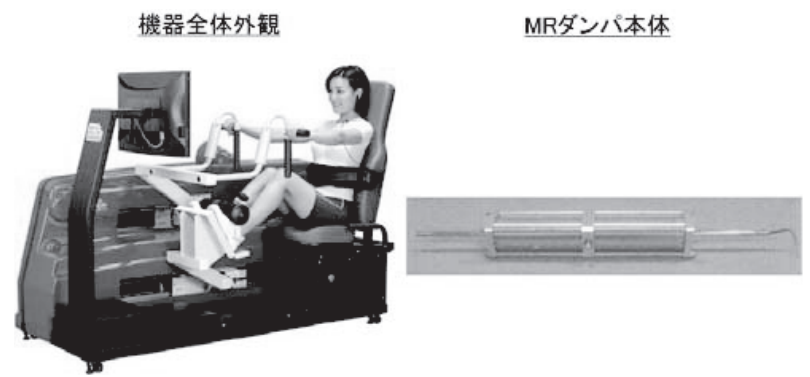

図 $9 \mathrm{MR}$ ダンパを用いたエクササイズ機器

ントが 2009 年より実用化されており，採用車種が拡大さ れてきている.

2.6 キャブサスペンション

欧州の農機メーカでは，入力振動が大きく変動する農作 業に対し，MR デバイスの幅広い減衰制御を用いた運席室 用サスペンションシステムを 2008 年から採用している（図 8).このシステムでは MR ダンパとエアスプリング，セン サ類から制御基板まで一体化されており, 容易に通常のオ イルダンパと入れ替えることができるようになっている。

\section{7 エクササイズ機器}

日本国内でも MR ダンパを利用したエクササイズ機器が 2011 年より市販されている（図 9）. 


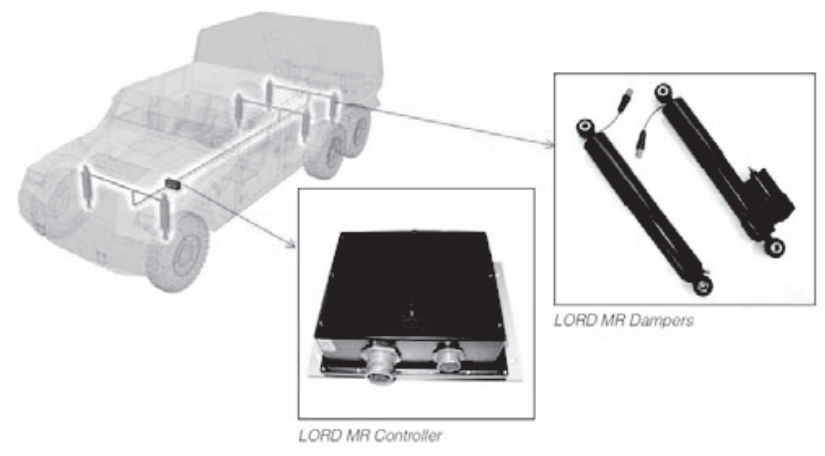

図 10 軍事車両向け MR ダンパシステム

MR の特性を活かし, 手脚の屈曲時と伸展時の両方の動 作に対して 1 本のダンパで減衰力を適時制御しながら適切 な負荷を与えることができるようになっている [4].

\section{3. 最近の応用事例}

\section{1 軍用車両用一次サスペンション}

米国では以前から軍用車両についての制御サスペンショ ンの検討が進んでいる（図 10）。

これまでの試験結果では, このシステムにより操縦安定 性の向上, ピッチ/ロールの低減, 最高速度の増加などで, 既存のシステムに比べ数十\%の性能向上が認められており, 更に副次的な効果として，車体への負荷低減による，ライ フサイクルコストの大幅な低減も報告されている [5].
3.2 モータサイクル用ステアリングダンパ

回転系のダンパでも応用が検討されている。フコントフ オークと車体の間に取り付けた MR ダンパの減衰力をリア ルタイムに調整することで安定性と操作性を両立させてい る $[6]$.

\section{参 考 文 献}

[1] 出頭, Yanyo： "MR 流体, 装置, システムの自動車への応用展開”, 自動車技術会 2005 年春季学術講演会前刷集, no.76-05, pp.25-28, 2005 .

[2 ] O. Raynauld and S. Fath: "Magneride suspension for the range rover evoque," ATZ worldwide eMagazines Edition: 2012-02, pp.16-20, 2012.

[3] D. Ivers and D. LeRoy: "Improving vehicle performance and operator ergonomics: Commercial application of smart materials and systems," Journal of Intelligent Material Systems and Structures, May 6, 2012.

[4] 竹井機器プレスリリース, http://www.takei-si.co.jp/productinfo/ detail/pdf/puresu2.pdf

[5] LORD 社ホームページ, http://www.lord.com/Products-andSolutions/Magneto-Rheological-(MR)/MR-Controllers.xml

[6] Hara et al.: Steering Damper for Motocross, JSAE 20119519/SAE 2011-32-0519.

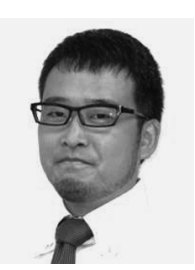

木本 彰 (Akira Kimoto)

2001 年静岡大学大学院機械工学科卒業. 2008 年よりロード・ファー・イースト社で MR 関 連製品の事業開発に従事。

E-mail: akira_kimoto@lord.com 